\title{
Duodenoscope-Acquired Infections: Risk Factors to Consider
}

\author{
Grace Thornhill ${ }^{1}$ Brian Dunkin² \\ ${ }^{1}$ Infection Prevention Fellow, Boston Scientific-Endoscopy, \\ Marlborough, Massachusetts, United States \\ ${ }^{2}$ Chief Medical Officer, Boston Scientific-Endoscopy, Marlborough, \\ Massachusetts, United States
}

\begin{abstract}
Address for correspondence Grace Thornhill, PhD, Infection Prevention Fellow, Boston Scientific-Endoscopy, 200 Boston Scientific Way, Marlborough, MA 01752-1234, United States (e-mail: grace.thornhill@bsci.com).
\end{abstract}

J Digest Endosc 2021;12:151-159.

\begin{abstract}
Keywords

- ERCP

- duodenoscope

- adverse events

- infection

- infection risk

In the wake of highly publicized duodenoscope-associated outbreaks caused by multidrug-resistant organisms (MDRO), a herculean effort was made to understand the conditions that led to these transmission events. Although there is now a clearer picture on how these outbreaks happened, there are still significant data gaps when it comes to understanding the rate of duodenoscope-acquired infections (DAls), especially in nonoutbreak situations. Recent publications indicate that DAls are still occurring and suggest that infection rates are higher than currently believed. Given this data gap, it is important to identify those patient populations that are most at risk of postprocedure infection, so that appropriate infection control measures may be implemented. Although those patients receiving antibiotic prophylaxis are most at risk for infection, there are additional risk factors that should be considered. For the purposes of this review, risk factors for infection were divided into three broad categories as follows: (1) those that increase patient susceptibility to infection, (2) those related to the endoscopic procedure, and (3) those factors that put reusable duodenoscope inventories at risk of contamination. Infection risk is a complex interaction between the immune status of the patient, the characteristics of the infectious agent (antibiotic sensitivity, virulence factors, and epidemiology), and the environment of care. Because of this complexity, any assessment of the risk of infection should be performed on a case-by-case basis. There is a dearth of information on infection risk for those patients undergoing endoscopic retrograde cholangiopancreatograpy (ERCP), especially in the context of the development and implementation of new device technology, and new endoscopic procedures that are increasing in complexity. This narrative review was developed using the Medical Subject Heading (MeSH) terms to perform an electronic search in PubMed with the goal of generating a summary of the patient, procedural, and duodenoscope-associated factors that increase the risk of infection in patients undergoing ERCP. This review provides practical information regarding the segmentation of ERCP patients by infection risk, so that endoscopists can make informed decisions about the risk benefits of using enhanced duodenoscope technologies in the care of their patients.
\end{abstract}

DOI https://doi.org/ $10.1055 / \mathrm{s}-0041-1739562$ ISSN 0976-5042 (c) 2021. Society of Gastrointestinal Endoscopy of India.

This is an open access article published by Thieme under the terms of the Creative Commons Attribution-NonDerivative-NonCommercial-License, permitting copying and reproduction so long as the original work is given appropriate credit. Contents may not be used for commercial purposes, or adapted, remixed, transformed or built upon. (https://creativecommons.org/licenses/by-nc-nd/4.0/). Thieme Medical and Scientific Publishers Pvt. Ltd. A-12, 2nd Floor, Sector 2, Noida-201301 UP, India 


\section{Introduction}

Despite the fact that there have been numerous worldwide outbreaks of duodenoscope-acquired infections (DAIs) in patients undergoing endoscopic retrograde cholangiopancreatograpy (ERCP) with resultant patient deaths, the rate of infection following endoscopic procedures is widely believed to be a rare event. ${ }^{1-3}$ The foundational assumptions that form the basis of this belief have been shown to be incorrect but a generally accepted number that reflects the risk of infection remains elusive. ${ }^{4}$ The issue is further complicated by the implementation of increasingly complex therapeutic procedures during ERCP and the introduction of new technologies intended to mitigate DAI risks (e.g., single-use duodenoscopes and single-use distal caps) where the risk of infection is unknown. In the face of these data gaps, it is important to identify known risk factors for infection, so that vulnerable patients most susceptible to DAIs may be identified. Segmenting ERCP patients by infection risk allows endoscopists to make more informed decisions about the risk-benefit ratio of using enhanced duodenoscope technology in the care of their patients.

The objective of this narrative review is to summarize patient, procedural, and duodenoscope-associated factors that increase the risk of infection in patients undergoing endoscopic retrograde cholangiopancreatography (ERCP). The approach to this review was to identify the medical Subject Heading (MeSH) terms for defined topics and use them to perform an electronic search in PubMed. Topics, search terms, and inclusion criteria are located in - Table $\mathbf{1}$.

\section{Identifying Risk Factors for Infection in Patients Undergoing Endoscopic Retrograde Cholangiopancreatograpy}

Understanding the risk factors that facilitate the transmission of infectious agents is important for preventing their spread and can also be used to identify those patients most vulnerable to infection. This review provides a practical list of risk factors that may impact a patient undergoing ERCP with the result of increased susceptibility to infection or colonization. It also defines risk factors that may put reusable duodenoscope inventories at risk for persistent contamination. This list is based on general principles of infection prevention, duodenoscope-associated outbreak investigation literature, clinical literature, and professional association guidelines. Actual post-ERCP infection and colonization rates in clinical practice are unknown, ${ }^{4,5}$ therefore not all risk factors are identified, making this list extensive but not comprehensive.

Infection risk depends on the complex interplay of patient status, characteristics of the infectious agent, and the environment of care ( - Table 2 ). Some factors can be controlled, whereas others require the implementation of interventions to mitigate their effect. Because of this complexity, assessment of infection risk is best performed on a case-by-case basis. ${ }^{6,7}$

All pathogenic organisms have a reservoir, a place where they can grow and that facilitates transmission. ${ }^{7,8}$ With
Table 1 Narrative review search strategy and selection criteria

\begin{tabular}{|c|c|c|}
\hline Topic & $\begin{array}{l}\text { The Medical Subject } \\
\text { Headings terms used to } \\
\text { search PubMed }\end{array}$ & $\begin{array}{l}\text { Inclusion } \\
\text { criteria }\end{array}$ \\
\hline $\begin{array}{l}\text { Patient factors: } \\
\text { susceptibility } \\
\text { to infection }\end{array}$ & $\begin{array}{l}\text { infection, immunocompro- } \\
\text { mised, cancer, transplanta- } \\
\text { tion, transplant recipients, } \\
\text { bone marrow transplant, } \\
\text { neutropenic, neutropenia, } \\
\text { malignancies, cholangi- } \\
\text { ocarcinoma, pancreatic } \\
\text { neoplasms, liver cancer, } \\
\text { hilar cholangiocarcinoma, } \\
\text { and cholangitis/sclerosing }\end{array}$ & \multirow{4}{*}{$\begin{array}{l}\text { Inclusion } \\
\text { criteria: English } \\
\text { language jour- } \\
\text { nals available } \\
\text { on PubMed. } \\
\text { Randomized } \\
\text { controlled } \\
\text { studies, nonran- } \\
\text { domized, and } \\
\text { retrospective } \\
\text { studies were } \\
\text { included. Papers } \\
\text { with limitations } \\
\text { were included } \\
\text { if more robust } \\
\text { studies were not } \\
\text { available }\end{array}$} \\
\hline $\begin{array}{l}\text { Patient } \\
\text { factors: risk of } \\
\text { post-proce- } \\
\text { dure infection }\end{array}$ & $\begin{array}{l}\text { endoscopy, gastrointesti- } \\
\text { nal, gastrointestinal endo- } \\
\text { scopes, ERCP, ERCP/adverse } \\
\text { effects, cholangiopancre- } \\
\text { atography, stents/adverse } \\
\text { effects, sphincterotomy, } \\
\text { stricture, stricture/malig- } \\
\text { nant, obstruction, bile duct } \\
\text { obstruction, cholecystitis, } \\
\text { choledocholithiasis, and } \\
\text { antibiotic prophylaxis }\end{array}$ & \\
\hline $\begin{array}{l}\text { Protection of } \\
\text { duodenoscope } \\
\text { inventory }\end{array}$ & $\begin{array}{l}\text { infection, } \\
\text { Enterobacteriaceae/infec- } \\
\text { tions, carbapenem-resist- } \\
\text { ant Enterobacteriaceae, } \\
\text { antibiotic resistance, } \\
\text { drug resistance/bacterial, } \\
\text { gram-negative bacteria/ } \\
\text { pathogenicity, cholangitis, } \\
\text { asymptomatic coloniza- } \\
\text { tion, asymptomatic carrier } \\
\text { state, and asymptomatic } \\
\text { infections, }\end{array}$ & \\
\hline Duodenoscope & $\begin{array}{l}\text { duodenoscopes, equipment } \\
\text { contamination, disease } \\
\text { outbreaks, carbapenems, } \\
\text { Enterobacteriaceae, infec- } \\
\text { tion control, cross infection/ } \\
\text { prevention \& control, dis- } \\
\text { infection, device/medical, } \\
\text { endoscopes, and biofilms }\end{array}$ & \\
\hline Guidelines & NA & $\begin{array}{l}\text { International } \\
\text { professional } \\
\text { gastroentero- } \\
\text { logical societies } \\
\text { searched for } \\
\text { guidelines on } \\
\text { adverse events } \\
\text { and antibiotic } \\
\text { prophylaxis, } \\
\text { and available in } \\
\text { English }\end{array}$ \\
\hline Reference lists & NA & $\begin{array}{l}\text { Reference lists } \\
\text { of included } \\
\text { peer-reviewed } \\
\text { articles were } \\
\text { examined for } \\
\text { relevant articles } \\
\text { to supplement } \\
\text { the electronic } \\
\text { search }\end{array}$ \\
\hline
\end{tabular}

Abbreviations: ERCP, endoscopic retrograde cholangiopancreatograpy; NA, not available. 
Table 2 General factors contributing to risk of infection ${ }^{14}$

\begin{tabular}{|l|l|}
\hline Patient status & $\begin{array}{l}\text { General health, Immune status, disease state, } \\
\text { anatomic/physiologic factors, medical history, } \\
\text { and immigration/travel history }\end{array}$ \\
\hline $\begin{array}{l}\text { Infectious } \\
\text { agent }\end{array}$ & $\begin{array}{l}\text { Prevalence, transmission route, antibiotic use, } \\
\text { pathogen or opportunist, duration of exposure, } \\
\text { infectious dose (ID } \text { ID }_{\text {of }} \text { ), virulence factors, antibi- } \\
\text { otic resistance, and species of microorganism }\end{array}$ \\
\hline $\begin{array}{l}\text { Environment } \\
\text { of care }\end{array}$ & $\begin{array}{l}\text { Type of health care facility (critical, long-term } \\
\text { health, and ambulatory surgery center), number } \\
\text { and type of procedures performed, staffing } \\
\text { ratios, length of stay, adherence to infec- } \\
\text { tion prevention protocols, and occupational } \\
\text { exposure }\end{array}$ \\
\hline
\end{tabular}

respect to patient infection and/or colonization associated with ERCP procedures, there are two significant pathogen reservoirs, the patient and the duodenoscope. A significant patient reservoir is the normal flora of the gastrointestinal (GI) tract. Duodenoscopes become reservoirs due to failures in reprocessing that lead to persistent biofilm formation. Reprocessing failures are common as illustrated in the Federal Drug Administration (FDA) mandated postmarket study conducted in response to DAI outbreaks in the United States which demonstrated up to a $5 \%$ contamination rate of patient-ready duodenoscopes after they were reprocessed using best practices. ${ }^{9}$ Other studies have shown contamination rates of patient-ready reusable duodenoscopes to be as high as $60 \% .^{10}$ Infections of endogenous origin are thought to be caused by translocation of normal flora into the blood stream during endoscopic procedures. ${ }^{2,11,12}$ It is currently unknown which fraction of ERCP-related infections are endogenous in origin and which fraction results from exogenous bacteria that originate in the environment (e.g., from a contaminated duodenoscope). ${ }^{10,13}$ Although there are likely additional reservoirs for those organisms involved in ERCP-related infections, at a minimum, infection risk assessments should consider patient risk factors and factors that put reusable duodenoscope inventories at risk for persistent contamination. ${ }^{14-16}$

For the purpose of this review, risk factors for infection have been divided into three broad categories as follows: (1) those that increase patient susceptibility to infection, (2) those inherent in the type of ERCP procedure being performed that contribute to postprocedure infection, and (3) those factors that put reusable duodenoscope inventories at risk of persistent contamination.

\section{Patient Factors: Increased Susceptibility to Infection}

The factors that render a patient more susceptible to infection are complex and have broad application to many disease states. ${ }^{6.7}$ This discussion focuses on those patient factors that are relevant to the ERCP patient.

\section{Immunocompromised}

The immunocompromised patient has defects in the body's normal defense mechanisms that predisposes them to life-threatening infections that may not otherwise occur. The degree of immune function may vary with time, therapy, and exposure to infectious agents. ${ }^{6}$ There are broad categories of host abnormality that are commonly associated with an impaired immune system that may impact the ERCP patient. ${ }^{2,6}$ Examples of these categories include cancer, transplant, age, pregnancy, occupation, residence, and travel/immigration status. Comorbidities may also contribute to infection risk in the immunocompromised ERCP patient. Examples include but are not limited to diabetes, eating disorder/poor nutritional status, drug/alcohol/tobacco addiction, chronic liver disease, and disease of the cardiopulmonary system. ${ }^{2,6,7}$ Along with immune system diseases, there are numerous patient factors that increase the risk of infection for the ERCP patient that are listed in - Table 3. The patient risk factors of most concern to the ERCP patient are malignancies and liver transplant candidates/recipients and are described in more detail below..$^{1,2}$

\section{Malignancies}

The risk of infection increases in patients with malignancies due to two major concerns, the malignancy itself and the effect of treatment. While all cancer patients are fragile and therefore at risk of infection, they do not all carry the same risk. Patients with acute hematologic cancers are of the greatest concern because they are at increased risk of bacteremia and sepsis after endoscopy. ${ }^{2,17}$ In addition, treatment of malignancies often includes use of cytotoxic chemotherapeutic drugs and/or radiation therapy, both of which suppress immune system function leading to a greater risk of infection. ${ }^{7,17,18}$ It is important to note that the incidence of bacteremia after ERCP ranges from 6.4\% (nonobstructed bile duct) to $18 \%$ (with biliary obstruction)., ${ }^{2,11}$ Such bacteremia in patients with malignancy may become clinically relevant. Bianco et al, in a retrospective study of 47 allogenic bone marrow transplant patients, found that 9 (19\%) developed clinically relevant bacteremia 24 hours after EGD. ${ }^{17}$ While there is no clinical data on the risk of infection for patients with acute hematologic cancers undergoing ERCP, published guidelines recommend a cautious approach in performing endoscopy in these patients and assessing their infection risk on an individual basis. ${ }^{1,2,19,20}$

Table 3 Patient factors that may increase susceptibility to infection

\begin{tabular}{|l|l|}
\hline Immunocompromised $^{1,2,6}$ & $\begin{array}{l}\text { Cancer, transplant, bone marrow } \\
\text { transplant, disease of immune sys- } \\
\text { tem, advanced hematologic cancers, } \\
\text { and severe neutropenia (absolute } \\
\text { neutrophil count <500 cells/mL) }\end{array}$ \\
\hline Malignancies $^{27}$ & $\begin{array}{l}\text { Cholangiocarcinoma, pancreatic } \\
\text { cancer, liver cancer, cytotoxic } \\
\text { chemotherapy drugs, and radiation } \\
\text { treatments }\end{array}$ \\
\hline Transplant $^{7,23-25}$ & $\begin{array}{l}\text { Liver transplant, transplant candi- } \\
\text { dates, transplant recipients, and } \\
\text { antirejection drug therapy }\end{array}$ \\
\hline
\end{tabular}




\section{Liver Transplant}

The risk of infection in the transplant patient is dependent on the interplay between exposure to infectious agents and their level of immunosuppression..$^{21}$ Infection is the most frequent cause of death following liver transplantation, particularly in the first year after transplant. ${ }^{22}$ Data from the United Network for Organ Sharing (UNOS) revealed the incidence of mortality for 64,977 first-time liver transplant recipients transplanted between February 2002 and June 2016 ranged between 5 and $10 \%$. Infections were the most frequent cause of death during 30 to 180 days after liver transplantation..$^{22}$ Gram-negative infections represent a major complication in liver transplant recipients with a frequency ranging between 20 and $80 \%$ of cases. Three-fourths of bacterial infectious episodes occur in the first month after transplantation contributing to longer hospital stays and increased costs. ${ }^{23}$

For patients on a transplant waiting list, development of an infection may rapidly change their suitability for a transplant. ${ }^{23-25}$ Transplant candidates may be temporarily suspended from the list until the infection is resolved or can be delisted if the infection is caused by a multidrug resistant organism (MDRO) or results in multiple organ failure. $^{23-25}$ In a retrospective analysis of consecutive patients listed for liver transplantation between 2007 and 2014 those with an infection were 5.2 times more likely to become delisted than noninfected patients. Infections occurred in 144 of 327 studied patients (44\%) with $23.4 \%$ of the patients on the liver transplantation waiting list delisted or deceased before transplantation. ${ }^{24}$

Interestingly, infectious complications and infection-associated acute-on-chronic liver failure (I-ACLF) seem to be increasing in potential transplant candidates. This is illustrated in a study conducted by 15 transplant centers that compose the North American Consortium for the Study of End-Stage Liver Disease (NACSELD). These centers enrolled patients in a prospective study structured to follow those admitted with cirrhosis who also had or developed one or more infections during hospitalization. ${ }^{25}$ Of the 136 patients enrolled, 57 (42\%) were delisted or deceased within 6 months of infection illustrating that infections can rapidly change a patient's survival in time for transplant or suitability for transplant. ${ }^{25}$ Because infection is the primary cause for delisting a transplant candidate, infection prevention, including efforts to prevent duodenoscope mediated cross-contamination, is critical.

The goal of preventing infections in transplant candidates and recipients faces multiple hurdles including the shifting worldwide epidemiology of infections, increasing prevalence of antimicrobial resistance, suboptimal assays for the microbiologic screening of organ donors, virus-associated malignancies, and persistently contaminated reusable duodenoscopes used in ERCP procedures.,21,26

\section{Procedure Factors Associated with Increased Infection Risk}

ERCP is considered a high-risk endoscopic procedure because it has one of the highest rates of postprocedure bacteremia ranging from 6.4 to $18 \% .^{1,2}$ In comparison, other endoscopic procedures that have known high rates of postprocedure bacteremia include esophageal dilation (12-22\%) and sclerotherapy of esophageal varices (up to 52\%).,12 Factors that increase the risk of post-ERCP infection are listed in - Table 4 and discussed in detail below.

\section{Obstruction}

Obstruction or stricture of a body passage is a recognized risk factor for infection. ${ }^{7}$ Incomplete drainage of an obstructed biliary system is the major predictor of post-ERCP biliary sepsis and cholangitis occurring in up to $3 \%$ of ERCP cases. Incomplete biliary drainage was predictive of $91 \%$ of all cases of sepsis associated with ERCP with the risk of post-ERCP cholangitis dependent on the nature and site of the obstruction (-Table 3 ) and the highest in patients with incomplete biliary drainage (e.g., hilar cholangiocarcinoma and primary sclerosing cholangitis) and prior history of liver transplantation. ${ }^{1}$

Although cholangitis is the most common infection that occurs after ERCP, ${ }^{1,2,27}$ ERCP-associated infections can occur in systems remote to the GI tract. ${ }^{2,26,28}$ During the course of a carbapenem-resistant Enterobacterales (CRE) outbreak associated with ERCP procedures, Kim et al found that $53.3 \%$ of CRE colonized patients who became actively infected had cultures positive for the outbreak strain coming from blood, bile, wound, the peritoneum, and the urinary tract. ${ }^{15}$ In a risk evaluation for duodenoscope-associated infections in the Netherlands, Kwakman et al reviewed three outbreak investigations involving MDROs. ${ }^{26}$ They also found that DAIs presented in locations remote from the GI system. Combining the numbers from all three outbreaks, they identified seven blood stream infections, three abdominal infections, one

Table 4 Patient and procedural factors that contribute to post-ERCP infection risk

\begin{tabular}{|l|l|}
\hline Obstruction ${ }^{2,7,15}$ & $\begin{array}{l}\text { Cholangiocarcinoma with hilar stricture, } \\
\text { cholangitis, malignant biliary stricture, } \\
\text { multiple strictures, acute cholecystitis, and } \\
\text { choledocholithiasis with incomplete stone } \\
\text { clearance }\end{array}$ \\
\hline $\begin{array}{l}\text { Prior proce- } \\
\text { dures } 1,7,15,34,60\end{array}$ & $\begin{array}{l}\text { ERCP, prior stent placement, stent replace- } \\
\text { ment, and biliary sphincterotomy }\end{array}$ \\
\hline $\begin{array}{l}\text { Multiple concur- } \\
\text { rent proce- } \\
\text { dures }\end{array}$ & $\begin{array}{l}\text { Choledochoscopy during ERCP, laparo- } \\
\text { scopic-assisted ERCP, tumor ablation, EUS } \\
\text { with biopsy, percutaneous hepatic stent } \\
\text { placement, and percutaneous intervention } \\
\text { in radiology + endoscopy procedures }\end{array}$ \\
\hline $\begin{array}{l}\text { Antibiotic } \\
\text { prophylaxis } \\
\text { - ASGE recom- } \\
\text { mendations and } \\
\text { suggestions }{ }^{1,2}\end{array}$ & $\begin{array}{l}\text { Known or suspected biliary obstruction, } \\
\text { where there is a possibility of incomplete } \\
\text { biliary drainage to include primary sclerosing } \\
\text { cholangitis, hilar cholangiocarcinoma, biliary } \\
\text { complications post-liver transplant, patients } \\
\text { with high-risk cardiac conditions and } \\
\text { established gastrointestinal tract infections } \\
\text { (for prevention of infective endocarditis), } \\
\text { EUS-fine needle aspiration for pancreatic and } \\
\text { mediastinal cysts/pseudocysts }\end{array}$ \\
\hline
\end{tabular}

Abbreviations: ASGE, the American Society for Gastrointestinal Endoscopy ERCP, endoscopic retrograde cholangiopancreatograpy; EUS, endoscopic ultrasound. 
respiratory infection, one cholangitis, and nine cases of sepsis. In another ERCP-associated outbreak investigation, Epstein et al reported that intestinal colonization can lead to remote sites of infection as evidenced by finding the outbreak strain in the urinary tract, pulmonary tree, bloodstream, and abscesses weeks to months after the initial ERCP procedure. ${ }^{16}$

\section{Prior and/or Multiple Concurrent Procedures}

Increased infection risk is seen in those patients who are having selected advanced, multiple, or concurrent procedures (-Table 4). Instrumentation and mechanical manipulation of tissues provides opportunities for the occurrence of transmission events. ${ }^{7}$ For example, biliary sphincterotomy is a risk factor for cholangitis. ${ }^{1}$ Freeman et al identified cholangitis in $1 \%$ of patients undergoing biliary sphincterotomy. Other significant risk factors include combined percutaneous endoscopic procedures $(p<0.001)$, stenting of malignant strictures $(p<0.001)$, and failed biliary access or drainage ( $p$ $<0.001)^{29}$

Placement of in-dwelling biliary stents to relieve obstruction from stones or malignancies may increase the risk of infection. ${ }^{15}$ Biofilm formation on stents is of concern as colonized stents provide a conduit for microbes to migrate to other ducts and tissues. ${ }^{1}$ An occluded stent, as it is pulled through a reusable duodenoscope, may seed the working channel of a reusable duodenoscope putting the duodenoscope inventory at risk for cross-contamination and transmission events. There is an increased risk of life-threatening acute cholangitis and sepsis in patients experiencing a sudden obstruction of bile flow due to stent occlusion. ${ }^{30,31}$ Occlusions of the stent lumen may be from stone fragments, bacterial biofilm, sludge, tumor and/or tissue ingrowth, and overgrowth. ${ }^{1,31}$ Occlusion and cholangitis may also occur because of stent migration in the setting of an obstructed bile duct., ${ }^{1,32}$ While investigating an ERCP-associated CRE outbreak, Kim et al found that, in patients undergoing ERCP with a contaminated duodenoscope, biliary stent placement was the only independent procedure-related risk factor associated with an increased risk for CRE infection (odds ratio [OR] $=3.62 ; 95 \%$ confidence interval $[\mathrm{CI}]$ : $1.12-11.67) .{ }^{15}$ When comparing patients who were actively infected versus colonized patients, they found that those with an active infection also underwent biliary stent placement ( 87.5 vs. $14.3 \%$; $\mathrm{P} Z=0.010$ ) more often than those who were colonized. ${ }^{33}$

In addition, the ERCP patient undergoing multiple or concurrent procedures may be at increased risk for infection. In a study that examined 72 patients who underwent single-operator choledochoscopy, 19\% of patients had sustained bacteremia following ERCP or choledochoscopy. ${ }^{34}$ Despite the use of postprocedure intravenous antibiotic administration, seven patients (9.7\%) required further antibiotic treatment for infectious complications with three hospitalizations required to receive intravenous antibiotic therapy. Sethi et al examined 4,214 ERCPs, 402 of which included cholangioscopy or pancreatoscopy. ${ }^{35}$ Compared with the ERCP-only cohort, patients undergoing cholangioscopy or pancreatoscopy had higher rates of adverse events ( 2.9 vs. $7 \%$,
$\mathrm{OR}=2.50$; 95\% CI: 1.56-3.89), and significantly higher rates of cholangitis ( 0.2 vs. $1 \%, \mathrm{OR}=4.98 ; 95 \% \mathrm{CI}: 1.06-19.67) .{ }^{35}$ In an analysis of surgical site infection (SSI) surveillance data, Loor et al found that patients undergoing ERCP within 60 days of a cholocystectomy had an increased SSI rate (4.1 vs. $1.8 \%$ ) compared with those procedures where ERCP was performed in the same setting. These findings underscore the principle that multiple procedures increase the risk of infection and suggest that pathogen transmission during ERCP may remain undetected until later invasive procedures. ${ }^{5,36}$

\section{Antibiotic Prophylaxis}

There is no clearer indication of infection risk than those situations where antibiotic prophylaxis is already recommended as part of society guidelines. Patients who meet the criteria for receiving pre-ERCP antibiotic prophylaxis based on existing guidelines should be considered at a higher risk for infection overall. The recommendations for antibiotic prophylaxis in ERCP patients from selected professional organizations are summarized in - Table 5. All associations recommend against the routine use of antibiotic prophylaxis for ERCP.,19,20 There are varying strengths of recommendations for certain high-risk patient populations and procedures. Of note are the disparities on recommendations for patients who are immunocompromised such as those with severe neutropenia or advanced hematologic malignancy. Acknowledging the lack of clinical evidence, the British and European guidelines recommend prophylactic antibiotics prior to endoscopy if the absolute neutrophil count (ANC) is less than $500 / \mathrm{mm}^{3}$ and the patient is undergoing a high-risk procedure, such as ERCP for an obstructed system. ${ }^{19,20}$ The American Society for Gastrointestinal Endoscopy (ASGE) recommendation is less clear. Citing insufficient evidence to recommend for or against administration of antibiotic prophylaxis before routine endoscopic procedures in patients with severe immunosuppression (absolute neutrophil count of $<500$ cells/mL, advanced hematologic malignancies, and bone marrow transplantation), they state that the use of antibiotic prophylaxis in these scenarios may be beneficial and should be individualized. ${ }^{2}$ Citing a lack of data, all guidelines agree that that patients with immunocompromised status but normal neutrophil counts (e.g., organ transplant recipients and patients with HIV) are at increased risk for GI endoscopy-related infections but do not recommend routine administration of prophylactic antibiotics in this setting (-Table 5).

- Table 5 records the variations in recommendations for antibiotic prophylaxis to prevent infectious endocarditis (IE). ASGE is the only professional society to recommend antibiotic prophylaxis for IE but only in those patients with high-risk cardiac conditions that also have active GI infections such as cholangitis. The rationale is that ERCP patients may be especially vulnerable because of the high rate of postprocedure bacteremia. The British guideline does not recommend antibiotic prophylaxis for infective endocarditis and the topic is not addressed in the European guideline on adverse events. 
Table 5 Antibiotic prophylaxis recommendations

\begin{tabular}{|c|c|c|c|}
\hline Recommendation & $\begin{array}{l}\text { American Society for } \\
\text { Gastroenterology, } 2015^{2}\end{array}$ & $\begin{array}{l}\text { European Society } \\
\text { for Gastrointestinal } \\
\text { Endoscopy, } 2020^{19}\end{array}$ & $\begin{array}{l}\text { British Society of } \\
\text { Gastroenterology, } \\
2009^{20}\end{array}$ \\
\hline $\begin{array}{l}\text { Against routine use of antibiotic } \\
\text { prophylaxis before ERCP }\end{array}$ & Yes & $\begin{array}{l}\text { Yes, strong recommendation, } \\
\text { moderate quality of evidence }\end{array}$ & Yes \\
\hline $\begin{array}{l}\text { Known or suspected biliary obstruc- } \\
\text { tion, where there is a possibility } \\
\text { of incomplete biliary drainage to } \\
\text { include primary sclerosing cholangi- } \\
\text { tis, hilar cholangiocarcinoma }\end{array}$ & Yes & $\begin{array}{l}\text { Yes, weak recommendation, } \\
\text { moderate quality of evidence }\end{array}$ & Yes \\
\hline $\begin{array}{l}\text { Biliary complications post liver } \\
\text { transplant }\end{array}$ & Yes & Not addressed & Yes \\
\hline $\begin{array}{l}\text { Endoscopic ultrasound-fine needle } \\
\text { aspiration for pancreatic and medi- } \\
\text { astinal cysts/pseudocysts }\end{array}$ & Yes, suggested & Not addressed & Yes \\
\hline $\begin{array}{l}\text { Patients with high-risk cardiac con- } \\
\text { ditions and established gastrointes- } \\
\text { tinal tract infections (for prevention } \\
\text { of infective endocarditis) }\end{array}$ & Yes & Not addressed & $\begin{array}{l}\text { No, patients with known } \\
\text { cardiac risks should be } \\
\text { followed closely for signs of } \\
\text { infection }\end{array}$ \\
\hline $\begin{array}{l}\text { Severely immunocompromised } \\
\text { patients }\end{array}$ & $\begin{array}{l}\text { No, prophylactic antibiotics } \\
\text { also may benefit patients with } \\
\text { severe neutropenia (absolute } \\
\text { neutrophil count of } 500 \text { cells/mL) } \\
\text { and/or advanced hematologic } \\
\text { malignancy. }\end{array}$ & $\begin{array}{l}\text { Yes, weak recommendation, } \\
\text { moderate quality of evidence }\end{array}$ & $\begin{array}{l}\text { Yes, patients with severe } \\
\text { neutropenia }(0.56109 / \mathrm{L}) \\
\text { and/or advanced hemato- } \\
\text { logical malignancy }\end{array}$ \\
\hline When performing cholangioscopy & Not addressed & $\begin{array}{l}\text { Yes, weak recommendation, } \\
\text { moderate quality of evidence }\end{array}$ & Not addressed \\
\hline
\end{tabular}

Abbreviation: ERCP, endoscopic retrograde cholangiopancreatograpy.

\section{Infections with Multidrug-Resistant Organisms}

Antibiotic prophylaxis recommendations are guided by the goal of providing information on the use of antibiotics, in part, to prevent the overuse and misuse of antibiotics that leads to the development of antibiotic-resistant bacteria. ${ }^{8}$ MDROs have been involved in over 32 ERCP-associated outbreaks. ${ }^{3,14,37,38}$ The most common MDRO involved were CRE bacteria which are becoming more prevalent, have few treatment options, and are associated with a high mortality rate. ${ }^{8}$ Reuken et al analyzed 1,764 isolates from bile cultures taken from ERCP patients and found that 24 of 89 patients were cultured positive for MDR bacteria. ${ }^{39}$ The univariate risk factors for these biliary MDR bacteria were male sex, nosocomial acute cholangitis, prior antibiotic exposure, and prior biliary stenting. Biliary stenting was the only independent risk factor according to multivariate analysis ( $\mathrm{OR}=3.8 ; 95 \%$ CI: $1.3-11.0, p=0.013){ }^{39}$

ERCP patients are at risk for MDRO infection from contaminated duodenoscopes. The infection rate has been under debate ever since Ofstead et al published a commentary in 2013 showing that the oft-quoted infection rate of 1 in 1.8 million for endoscopic procedures was incorrect. ${ }^{4}$ Since 2013, the GI community has not come to a consensus on the rate of infection after ERCP mainly due to the fact that there is a paucity of solid data on the topic. A study out of the Netherlands performed a systematic literature search to identify all DAI outbreaks between 2008 and 2018. ${ }^{26}$ They calculated a minimum risk of duodenoscope-associated infection as $0.01 \%$ which was at least 180 times higher than previously published risk estimates of infection after endoscopy. ${ }^{26}$ The risk of becoming colonized with an MDRO was calculated at being at least 0.023 to $0.029 \%{ }^{26}$ They proposed that the actual risk is likely to be much higher due to underreporting of both MDRO infections and those caused by sensitive bacteria.

Du et al used automated surveillance to identify infections that occurred after ERCP in one of the largest tertiary hospitals in China between 2012 and 2015.8 Infection control personnel and physicians confirmed all identified healthcare-associated infections (HAIs; e.g., cholangitis and bacteremia). From the 1,743 ERCP procedures that were included in the study, 132 HAIs were identified. The most prevalent HAI was biliary tract infection (4.02\%), followed by transient bacteremia (1.14\%). The most prevalent bacterial isolates were Enterococcus faecium and Escherichia coli. A large proportion (73\%) of the E. coli isolates and all of the E. faecium isolates were resistant to ciprofloxacin. In addition, only $37 \%$ of the $E$. coli isolates were susceptible to ceftriaxone. $^{28}$

Ofstead posits that evidence-based calculations of DAI risk can be made from estimates of pathogen transmission using duodenoscope contamination rates. ${ }^{5}$ Contamination rates from different sources were used that ranged from $0.3 \%$ in academic centers to 5\% in FDA postmarket surveillance studies to $22 \%$ in 67 Dutch hospitals and $60 \%$ in other high-volume settings. With approximately 750,000 annual ERCP procedures 
in the United States, the predicted number of ERCPs performed annually with contaminated patient-ready reusable duodenoscopes was calculated to range from 2,250 to 412,500 . Using an average attack rate of $18.9 \%$ Ofstead then calculated a range of per-procedure pathogen transmission, resulting in rates of 1 in 1,765 ( $0.3 \%$ contaminated) to 1 in 106 (5\% contaminated), 1 in 24 ( $22 \%$ contaminated), and 1 in 10 ERCP procedures (60\% contaminated) depending on which contamination rate is used. ${ }^{5}$

\section{Protection of Duodenoscope Inventory}

\section{Active Patient Infection and Colonization}

Reusable duodenoscopes (with or without removable endcaps) exposed to patients with active infections are at risk of becoming persistently contaminated with pathogenic organisms. These contaminated scopes increase the risk of patient infection and colonization in each patient in which they are used. ${ }^{15,40}$ The emphasis on protection of duodenoscope inventory has evolved as the GI community has become aware of pathogen transmissions and outbreaks associated with ERCP procedures. Currently, the focus is on the emerging MDROs involved in these outbreaks but there should also be concern for infections caused by pan-sensitive pathogens with a less remarkable profile, as they also result in significant patient morbidity and mortality. ${ }^{10}$ Active infections, such as cholangitis, cholecystitis, localized infection, and septicemia, all present risk for contamination of a duodenoscope inventory. ${ }^{15,16,41,42}$ Patients colonized with pathogenic organisms are of concern as well because they may be asymptomatic or present with subclinical symptoms making them undetectable unless active screening is performed. A small number of facilities in the United States have reported patient MDRO screening results on ERCP patients. Positive MDRO results ranged from 0.6 to $3.2 \% .{ }^{43-45}$ Colonization also poses a risk to the patient as conversion to active infection may happen over a period of weeks to years. ${ }^{46}$ Public health studies that screen healthy individuals for carriage of MDROs are lacking. Current estimates of the prevalence of asymptomatic carriage in the United States are largely based on estimates of community-onset infections. ${ }^{8}$ Jernigan et al reported on community-onset infections for both CRE and extended spectrum $\beta$-lactamase (ESBL)-producing Enterobacterales and found an increase from 19.1 to $64.1 \%$ between 2012 and 2017 . Travel history and immigration status may be an important factor, as well as there are many regions of the world where MDROs are endemic. ${ }^{47,48}$

\section{Persistent Contamination of Duodenoscopes}

Persistent contamination of a duodenoscope results from the interplay of events involving exposure to infected/colonized patients, ineffective reprocessing protocols, and complex duodenoscope design., ${ }^{5,15,41,49}$ Despite the best efforts to follow current reprocessing guidelines, an endoscope that is known to be contaminated can remain contaminated despite multiple rounds of reprocessing., ${ }^{5,15,41,49}$ Persistent contamination indicates that duodenoscope processing is ineffective. ${ }^{9}$ The primary culprit that impedes effective reprocessing is the presence of biofilm which can be extremely difficult or impossible to remove even with adherence to the best practice reprocessing protocols..$^{50,51}$ The primary factors that contribute to persistent biofilm formation and microbial contamination are mentioned below:

- Normal use of an endoscope results in damage to the working channel that may include luminal shredding, scratches, gouges, staining, and persistent debris, all of which provide a "safe harbor" for biofilm. ${ }^{52-54}$

- Inadequate manual cleaning impedes high-level disinfection/sterilization. ${ }^{49}$

- Incomplete drying resulting in storage of wet endoscopes which promotes biofilm formation. ${ }^{55,56}$

- Complex endoscope design impedes proper reprocessing. ${ }^{49}$

Based on data from FDA postmarket surveillance studies, up to 1 in 20 patient-ready duodenoscopes may be contaminated with pathogenic organisms. ${ }^{9,57-59}$ Contributing to this persistent contamination problem is the ongoing issue of lack of adherence to manufacturer instructions for use (IFU) for reprocessing reusable duodenoscopes. The FDA mandated observational study on the ability of users to adhere to IFUs showed high failure rates (25-94\%) when performing the manual cleaning steps for duodenoscope reprocessing. Due to these ongoing challenges, contaminated duodenoscopes are now recognized as a risk factor for transmission of infection to ERCP patients. ${ }^{1}$

\section{Conclusion}

A patient's risk of developing an infection after ERCP involves contributions from patient and procedural factors, pathogen characteristics, and environmental factors (e.g., a contaminated duodenoscope), and therefore should be assessed on a case-by-case basis. While data on the true risk of infection after ERCP is evolving, what is known is that the risks are significant. Reducing this risk of infection for ERCP patients will require the generation of robust data from studies focused on post-ERCP infection and colonization rates. Studies are also needed to assess the impact on infection risk after adoption of new technologies (device and device processing) and implementation of new, more complex procedures. Given that DAIs can be severe and life-threatening, infection prevention efforts are critical to providing high-quality patient care for these common procedures.

\section{Disclosures}

G.T. and B.D. are full-time employees of Boston Scientific. Brian Dunkin has ownership interest in Allotrope Medical.

\section{Authors' Contributions}

G.T. conceptualized, researched, and prepared the manuscript and compiled the tables. B.D. conceptualized, edited, and reviewed the manuscript.

\section{Conflict of Interest}

None declared. 


\section{References}

1 Chandrasekhara V, Khashab MA, Muthusamy VR, et al; ASGE Standards of Practice Committee. Adverse events associated with ERCP. Gastrointest Endosc 2017;85(1):32-47

2 Khashab MA, Chithadi KV, Acosta RD, et al; ASGE Standards of Practice Committee. Antibiotic prophylaxis for GI endoscopy. Gastrointest Endosc 2015;81(1):81-89

3 United States Senate: Health, Education, Labor, and Pensions Committee. Preventable tragedies: superbugs and how ineffective monitoring of medical device safety fails patients.. Available at: https://www.help.senate.gov/imo/media/doc/ Duodenoscope\%20Investigation\%20FINAL\%20Report.pdf. Accessed June 24, 2021

4 Ofstead CL, Dirlam Langlay AM, Mueller NJ, Tosh PK, Wetzler HP. Re-evaluating endoscopy-associated infection risk estimates and their implications. Am J Infect Control 2013;41(8):734-736

5 Ofstead CL, Buro BL, Hopkins KM, Eiland JE, Wetzler HP, Lichtenstein DR. Duodenoscope-associated infection prevention: a call for evidence-based decision making. Endosc Int Open 2020;8(12):E1769-E1781

6 Flood A. The immunocompromised host. Available at: https:// text.apic.org/toc/microbiology-and-risk-factors-for-transmission/the-immunocompromised-host. Accessed June 24, 2021

7 Fiutem C. Risk factors facilitating transmission of infectious agents 2014. Available at: https://text.apic.org/toc/microbiology-and-risk-factors-for-transmission/risk-factors-facilitating-transmission-of-infectious-agents. Accessed June 24, 2021

8 United States Centers for Disease Control and Prevention. Antibiotic resistance threats in the United States, 2019. Available at: https://www.cdc.gov/drugresistance/pdf/ threats-report/2019-ar-threats-report-508.pdf. Accessed June 24,2021

9 United States Food and Drug Administration. The FDA is recommending transition to duodenoscopes with innovative design to enhance safety: FDA Safety Communication. Available at: https://www.fda.gov/medical-devices/safety-communications/fda-recommending-transition-duodenoscopes-innovative-designs-enhance-safety-fda-safety-communication?utm_campaign=2019-08-29\%20CDRH\%20 Safety\%20Comm\%20-\%20\%20Recommendations\%20and\%20 Updates\%20to\%20Help\%20Improve\%20Duodenoscope\%20 Reprocessing\&utm_medium=email\&utm_source=Eloqua\#reprocessing. Accessed June 24, 2021

10 Thornhill G, David M. Endoscope-associated infections: a microbiologist's perspective on current technologies. Tech Gastrointest Endosc 2019;21(4):1-12

11 Nelson DB. Infectious disease complications of GI endoscopy: part I, endogenous infections. Gastrointest Endosc 2003;57(4):546-556

12 Chan BPH, Berzin TM. The endoscopy patient as a vector and victim. Gastrointest Endosc Clin N Am 2020;30(4):745-762

13 Rauwers A, Kwakman JA, Vos MC, Bruno MJ. Endoscope-associated infections: a brief summary of the current state and views toward the future. Tech Gastrointest Endosc 2019;21(4):150608

14 Rubin ZA, Kim S, Thaker AM, Muthusamy VR. Safely reprocessing duodenoscopes: current evidence and future directions. Lancet Gastroenterol Hepatol 2018;3(7):499-508

15 Kim S, Russell D, Mohamadnejad M, et al. Risk factors associated with the transmission of carbapenem-resistant enterobacteriaceae via contaminated duodenoscopes. Gastrointest Endosc 2016;83(6):1121-1129

16 Epstein L, Hunter JC, Arwady MA, et al. New Delhi metallo$\beta$-lactamase-producing carbapenem-resistant Escherichia coli associated with exposure to duodenoscopes. JAMA 2014; 312(14):1447-1455
17 Bianco JA, Pepe MS, Higano C, Applebaum FR, McDonald GB, Singer JW. Prevalence of clinically relevant bacteremia after upper gastrointestinal endoscopy in bone marrow transplant recipients. Am J Med 1990;89(2):134-136

18 Tong MC, Tadros M, Vaziri H. Endoscopy in neutropenic and/or thrombocytopenic patients. World J Gastroenterol 2015;21(46):13166-13176

19 Dumonceau J-M, Kapral C, Aabakken L, et al. ERCP-related adverse events: European Society of Gastrointestinal Endoscopy (ESGE) Guideline. Endoscopy 2020;52(2):127-149

20 Allison MC, Sandoe J A T, Tighe R, Simpson IA, Hall RJ, Elliott TSJ; Endoscopy Committee of the British Society of Gastroenterology. Antibiotic prophylaxis in gastrointestinal endoscopy. Gut 2009;58(6):869-880

21 Fishman JA. Infection in organ transplantation. Am J Transplant 2017;17(4):856-879

22 Baganate F, Beal EW, Tumin D, et al. Early mortality after liver transplantation: Defining the course and the cause. Surgery 2018;164(4):694-704

23 Fagiuoli S, Colli A, Bruno R, et al; 2011 AISF Single Topic Group. Management of infections pre- and post-liver transplantation: report of an AISF consensus conference. J Hepatol 2014;60(5):1075-1089

24 Alferink LJM, Oey RC, Hansen BE, et al. The impact of infections on delisting patients from the liver transplantation waiting list. Transpl Int 2017;30(8):807-816

25 Reddy KR, O'Leary JG, Kamath PS, et al; North American Consortium for the Study of End-Stage Liver Disease. High risk of delisting or death in liver transplant candidates following infections: results from the North American Consortium for the Study of End-Stage Liver Disease. Liver Transpl 2015;21(7):881-888

26 Kwakman JA, Erler NS, Vos MC, Bruno MJ. Risk evaluation of duodenoscope-associated infections in the Netherlands calls for a heightened awareness of device-related infections: a systematic review. Endoscopy 2021

27 Mallery JS, Baron TH, Dominitz JA, et al; Standards of Practice Committee. American Society for Gastrointestinal Endoscopy. Complications of ERCP. Gastrointest Endosc 2003;57(6): 633-638

28 Du M, Suo J, Liu B, Xing Y, Chen L, Liu Y. Post-ERCP infection and its epidemiological and clinical characteristics in a large Chinese tertiary hospital: a 4-year surveillance study. Antimicrob Resist Infect Control 2017;6:131

29 Freeman ML, Nelson DB, Sherman S, et al. Complications of endoscopic biliary sphincterotomy. N Engl J Med 1996;335(13):909-918

30 Kwon C-I, Lehman GA. Mechanisms of biliary plastic stent occlusion and efforts at prevention. Clin Endosc 2016;49(2):139-146

31 Motte S, Deviere J, Dumonceau J-M, Serruys E, Thys J-P, Cremer M. Risk factors for septicemia following endoscopic biliary stenting. Gastroenterology 1991;101(5):1374-1381

32 Brock AS, Steed LL, Freeman J, Garry B, Malpas P, Cotton P. Endoscope storage time: assessment of microbial colonization up to 21 days after reprocessing. Gastrointest Endosc 2015;81(5):1150-1154

33 Fejkeh MP, Phan J, Marya NB, Kim S, Rubin Z, Muthusamy R. Getting to zero: enhanced reprocessing and future directions. Tech Gastrointest Endosc 2019;21:150626

34 Thosani N, Zubarik RS, Kochar R, et al. Prospective evaluation of bacteremia rates and infectious complications among patients undergoing single-operator choledochoscopy during ERCP. Endoscopy 2016;48(5):424-431

35 Sethi A, Chen YK, Austin GL, et al. ERCP with cholangiopancreatoscopy may be associated with higher rates of complications than ERCP alone: a single-center experience. Gastrointest Endosc 2011;73(2):251-256 
36 Loor MM, Morancy JD, Glover JK, Beilman GJ, Statz CL. Single-setting endoscopic retrograde cholangiopancreatography (ERCP) and cholecystectomy improve the rate of surgical site infection. Surg Endosc 2017;31(12):5135-5142

37 Kovaleva J, Peters FT, van der Mei HC, Degener JE. Transmission of infection by flexible gastrointestinal endoscopy and bronchoscopy. Clin Microbiol Rev 2013;26(2):231-254

38 Dirlam Langlay AM, Ofstead CL, Mueller NJ, Tosh PK, Baron TH, Wetzler HP. Reported gastrointestinal endoscope reprocessing lapses: the tip of the iceberg. Am J Infect Control 2013;41(12):1188-1194

39 Reuken PA, Torres D, Baier M, et al. Risk factors for multi-drug resistant pathogens and failure of empiric first-line therapy in acute cholangitis. PLoS One 2017;12(1):e0169900

40 Humphries RM, Yang S, Kim S, et al. Duodenoscope-related outbreak of a carbapenem-resistant Klebsiella pneumoniae identified using advanced molecular diagnostics. Clin Infect Dis 2017;65(7):1159-1166

41 Wendorf KA, Kay M, Baliga C, et al. Endoscopic retrograde cholangiopancreatography-associated AmpC Escherichia coli outbreak. Infect Control Hosp Epidemiol 2015;36(6):634-642

42 Baggs J, Jernigan JA, Halpin AL, Epstein L, Hatfield KM, McDonald LC. Risk of subsequent sepsis within 90 days after a hospital stay by type of antibiotic exposure. Clin Infect Dis 2018;66(7):1004-1012

43 Olafsdottir LB, Wright SB, Smithey A, et al. Adenosine triphosphate quantification correlates poorly with microbial contamination of duodenoscopes. Infect Control Hosp Epidemiol 2017;38(6):678-684

44 Higa JT, Choe J, Tombs D, Gluck M, Ross AS. Optimizing duodenoscope reprocessing: rigorous assessment of a culture and quarantine protocol. Gastrointest Endosc 2018;88(2):223-229

45 Smith ZL, Oh YS, Saeian K, et al. Transmission of carbapenemresistant Enterobacteriaceae during ERCP: time to revisit the current reprocessing guidelines. Gastrointest Endosc 2015; 81(4):1041-1045

46 Thornhill G, Talapa L, Wallace C. An approach to improving the quality and consistency of flexible GI endoscope reprocessing. Available at: https://multimedia.3m.com/mws/media/ 10861410/improving-the-quality-of-flexible-gi-endoscopereprocessing.pdf. Accessed September 20, 2021

47 Logan LK, Weinstein RA. The epidemiology of carbapenem-resistant enterobacteriaceae: the impact and evolution of a global menace. J Infect Dis 2017;215(suppl_1): S28-S36

48 Martin RM, Bachman MA. Colonization, infection, and the accessory genome of Klebsiella pneumoniae. Front Cell Infect Microbiol 2018;8:4
49 United States Food and Drug Administration. Design of endoscopic retrograde cholangiopancreatography (ERCP) duodenoscopes may impede effective cleaning: FDA safety communication 2015 Available at: http://wayback. archive-it.org/7993/20170722213105/https://www.fda.gov/ MedicalDevices/Safety/AlertsandNotices/ucm434871.htm. Accessed June 24, 2021

50 Alfa MJ, Singh H, Nugent Z, et al. Simulated-use polytetrafluoroethylene biofilm model: repeated rounds of complete reprocessing lead to accumulation of organic debris and viable bacteria. Infect Control Hosp Epidemiol 2017;38(11):1284-1290

51 Alfa MJ. Medical instrument reprocessing: current issues with cleaning and cleaning monitoring. Am J Infect Control 2019;47S:A10-A16

52 Thaker AM, Kim S, Sedarat A, Watson RR, Muthusamy VR. Inspection of endoscope instrument channels after reprocessing using a prototype borescope. Gastrointest Endosc 2018;88(4):612-619

53 Ofstead CL, Wetzler HP, Snyder AK, Horton RA. Endoscope reprocessing methods: a prospective study on the impact of human factors and automation. Gastroenterol Nurs 2010;33(4):304-311

54 Ofstead CL, Hopkins KM, Eiland JE, Wetzler HP. Widespread clinical use of simethicone, insoluble lubricants, and tissue glue during endoscopy: a call to action for infection preventionists. Am J Infect Control 2019;47(6):666-670

55 Alfa MJ, Singh $\mathrm{H}$. Impact of wet storage and other factors on biofilm formation and contamination of patient-ready endoscopes: a narrative review. Gastrointest Endosc 2020;91(2):236-247

56 Ofstead CL, Heymann OL, Quick MR, Eiland JE, Wetzler HP. Residual moisture and waterborne pathogens inside flexible endoscopes: evidence from a multisite study of endoscope drying effectiveness. Am J Infect Control 2018;46(6):689-696

57 United States Food and Drug Administration. 522 postmarket surveillance studies database. Available at: https://www. accessdata.fda.gov/scripts/cdrh/cfdocs/cfPMA/pss.cfm?t id=353\&__id=3725. Accessed June 24, 2021

58 United States Food and Drug Administration. 522 postmarket surveillance studies database. Available at: https://www. accessdata.fda.gov/scripts/cdrh/cfdocs/cfPMA/pss.cfm?t id=355\&c_id=3727. Accessed June 24, 2021

59 United States Food and Drug Administration. 522 Postmarket Surveillance Studies database. Available at: https://www. accessdata.fda.gov/scripts/cdrh/cfdocs/cfPMA/pss.cfm?t_ id=354\&__id=3726. Accessed June 24, 2021

60 Wang P, Xu T, Ngamruengphong S, Makary MA, Kalloo A, Hutfless S. Rates of infection after colonoscopy and osophagogastroduodenoscopy in ambulatory surgery centres in the USA. Gut 2018;67(9):1626-1636 